\title{
THE EFFECT OF MULCHING ON SOIL TEMPERATURE, WINTER POTATO (SOLANUM TUBEROSUM L.) GROWTH AND YIELD IN FIELD EXPERIMENT, SOUTH CHINA
}

\author{
LI, X. B. ${ }^{1,2 \dagger}-$ SUO, H. C. ${ }^{1,2 \dagger}-$ AN, K. ${ }^{1,2}-$ FANG, Z. W. ${ }^{1,2}-$ WANG, L. ${ }^{1,2}-$ ZHANG X. L. ${ }^{1,2}-$ LIU, X. J. ${ }^{1,{ }^{*}}$ \\ ${ }^{I}$ The Crop Research Institute, Guangdong Academy of Agriculture \\ 18 Jinying West 2nd Street, 510640 Guangzhou, Guangdong, China \\ ${ }^{2}$ Key Laboratory of Crop Genetics and Improvement of Guangdong Province \\ 20 Jinying, 510640 Guangzhou, Guangdong, China \\ *Corresponding author \\ e-mail: 13609741790@163.com; phone: +86-20-3703-8559; fax: +86-20-8551-4269 \\ ${ }^{t}$ These authors have contributed equally to this work. \\ (Received $8^{\text {th }}$ Aug 2017; accepted $11^{\text {th }}$ Jan 2018)
}

\begin{abstract}
The growth of winter potato, which is mainly planted in South China, is negatively affected by low temperatures. However, mulching is an effective method to increase soil temperatures. Here, the effects of black plastic, white plastic and rice straw mulch were assessed on soil temperatures, as well as on potato growth and yield through field experiment. The daily mean temperatures increased by up to $7.5^{\circ} \mathrm{C}$ and $6.5^{\circ} \mathrm{C}$ under black and white plastic mulch, respectively, compared with no mulch. Furthermore, the emergence rates and dates were accelerated by mulching, with the greatest tuber yields being observed under the black mulch treatment in two growing seasons. Additionally, mulching altered the soil's fertility properties and soil microorganism composition. Taken together, mulching with black plastic film is an effective method that benefits winter potato production in Typical Pearl River Delta Plain in south China.
\end{abstract}

Key words: plastic mulch, soil fertility, potato yield, emergence rate, soil temperature

\section{Introduction}

Potato (Solanum tuberosum L.) is an important crop worldwide; ranking fourth after rice, wheat and maize, and it has a significant economic role. Currently, China is the largest potato producer in the world (FAO, 2014). In China, the North China Plain and Loess Plateau are major potato production regions because of their environmental conditions, including high altitudes, large diurnal air temperature fluctuations and abundant sunlight. However, these areas have typical arid and semiarid climates in which water scarcity is a substantial threat to crop yields (Wang et al., 2005). Thus, water-saving becomes the most critical factor in enhancing potato yield and quality. Mulching improves water conservation by reducing soil evaporation rates and increasing the water-use efficiency. Plastic mulch combined with drip irrigation has been used as an effective water-saving measure for the cultivation of potato in North China (Wang et al., 2011a; Liu et al., 2017; Zhang et al., 2017a).

In addition to saving water, plastic mulching also decreases nitrate leaching (Johnie and Josiah, 1998; Pat and Brenda, 2002; Romic et al., 2003), suppresses weed populations (Ghosh et al., 2006; Ramakrishna et al., 2006), kills pathogens (Vos et al., 1995; Triki et al., 2001), decreases soil bulk densities (Anikwe et al., 2007) and regulates soil temperature (Baghour et al., 2002; Ramakrishna et al., 2006; Wang et al., 2009; Hou et al., 2010; Ibarra-Jiménez et al., 2011; Dvořák et al., 2012; Zhao et al., 
2012). Reports on potato yield when plastic mulch is used are controversial, with some studies describing yield reductions (Baghour et al., 2002; Wang et al., 2009, 2011b), while others yield increases (Mahmood et al., 2002; Wang et al., 2005, 2009; Hou et al., 2010; Zhao et al., 2012, 2014; Ruízmachuca et al., 2014; Zhang et al., 2017b). These discrepancies may be attributed to differences in weather conditions among locations and study years, as well as soil temperature differences between mulched and nonmulched soil (Hou et al., 2010). Soil temperature is a main factor that regulates biomass accumulation, potato canopy development and potato tuber growth (Wolf et al., 1990; Delden et al., 2000). The optimum temperature for potato growth ranges from $15^{\circ} \mathrm{C}$ to $18^{\circ} \mathrm{C}$. Tuberization occurs at low temperatures below $21^{\circ} \mathrm{C}$ and is delayed, or even inhibited, at temperatures above $30^{\circ} \mathrm{C}$ (Hay and Allen, 1978).

The South China provinces of Guangdong, Guangxi, Hainan and Fujian form a major winter potato production region. It has a typical sub-tropical and tropical monsoon climate, with plentiful annual rainfall, but the daily mean temperature is higher than $25^{\circ} \mathrm{C}$ from May to October. Thus, potato growth is restricted in the winter (November to March) in fallow paddy fields. Winter potato production is a significant component in meeting the market demand for potatoes in the spring and in realizing all-year production and a year-round supply. However, temperatures below $15^{\circ} \mathrm{C}$ often occur during the potato growing season, especially in the early growing period, and sometimes the temperature falls below $0^{\circ} \mathrm{C}$, which threatens the winter potato yield. Fortunately, increased soil temperatures caused by mulching were noticed by farmers, and plastic mulch, as well as rice straw mulch, has been widely employed in winter potato production. While there is plenty of information regarding the plastic mulch and spring potato production in North China (Wang et al., 2005, 2009, 2011a; Zhao et al., 2012, 2014), there is little information concerning winter potato production under mulch in South China. In this study, the effects of plastic and rice straw mulch on winter potato growth were explored. The objectives of this study were to (1) evaluate the effects of mulch on soil temperature during the winter growing season; (2) assess the influence of mulch on the emergence rate and date, and the tuber size and yield of winter potato; and (3) explore the changes in soil fertility properties and microorganisms under mulch.

\section{Materials and methods}

\section{Experimental site}

Field experiments were carried out in 2013 to 2014 and 2014 to 2015 at Baiyun Experimental Station of Guangdong Academy of Agricultural Sciences in Guangzhou. It has a typical sub-tropical monsoon climate and has two or three harvests per year. Table 1 is the brief description of this experimental site. The Global Position System (GPS) coordinates of the experimental site was shown in Figure 1.

\section{Experimental design}

The experiment was designed as a randomized complete block with three replications and the following four treatments: (1) Black plastic mulch, (2) White plastic mulch, (3) Rice straw mulch, and (4) Bare soil. The plastic was $135 \mathrm{~cm}$ wide and $0.02 \mathrm{~mm}$ thick polyethylene film. The main agronomic management practises are shown in Table 2 . 


\section{Temperature measurements}

Weather data were obtained from the weather station located near the experimental site. Soil temperatures for each treatment were measured with $\mathrm{HOBO}^{\circledR}$ 12-Bit Temperature Smart Sensor Manual connecting with $\mathrm{HOBO}^{\circledR}$ Micro Station Quick Start (Onset Computer Corporation, Pocasset, United States), which were placed in the centre of the middle bed at soil depths of $5 \mathrm{~cm}, 10 \mathrm{~cm}, 15 \mathrm{~cm}, 20 \mathrm{~cm}$ and $25 \mathrm{~cm}$.

Table 1. Brief description of experimental site

\begin{tabular}{c|c|c}
\hline Items & Value & Annotation \\
\hline Location & & $\begin{array}{c}\text { Lies in Baiyun Experimental Station of } \\
\text { Guangdong Academy of Agricultural } \\
\text { Sciences in Guangzhou, Guangdong } \\
\text { province, South China }\end{array}$ \\
Altitude $(\mathrm{m})$ & $113^{\circ} 17 \mathrm{E}^{\prime}, 23^{\circ} 8 \mathrm{~N}^{\prime}$ & The average of 1951-2008 \\
Air temperature $\left({ }^{\circ} \mathrm{C}\right)$ & & \\
Average & 20.8 & In July \\
Maximum & 39.0 & In January \\
Minimum & 0 & \\
Precipitation $(\mathrm{mm})$ & 1738 & \\
Evaporation $(\mathrm{mm})$ & 1700 & \\
Sunshine hours $(\mathrm{h})$ & $>1800$ & \\
Groundwater table $(\mathrm{m})$ & $<10$ & \\
Average bulk density $\left(\mathrm{cm}{ }^{-3}\right)$ & 1.33 & \\
Frost-free period, day $(\mathrm{d})$ & 320 & \\
Major crops & Rice & \\
Pre-crop & Rice & \\
Land surface & Typical Pearl River Delta & \\
& Plain, the main land-use type is & \\
paddy field & \\
\hline
\end{tabular}

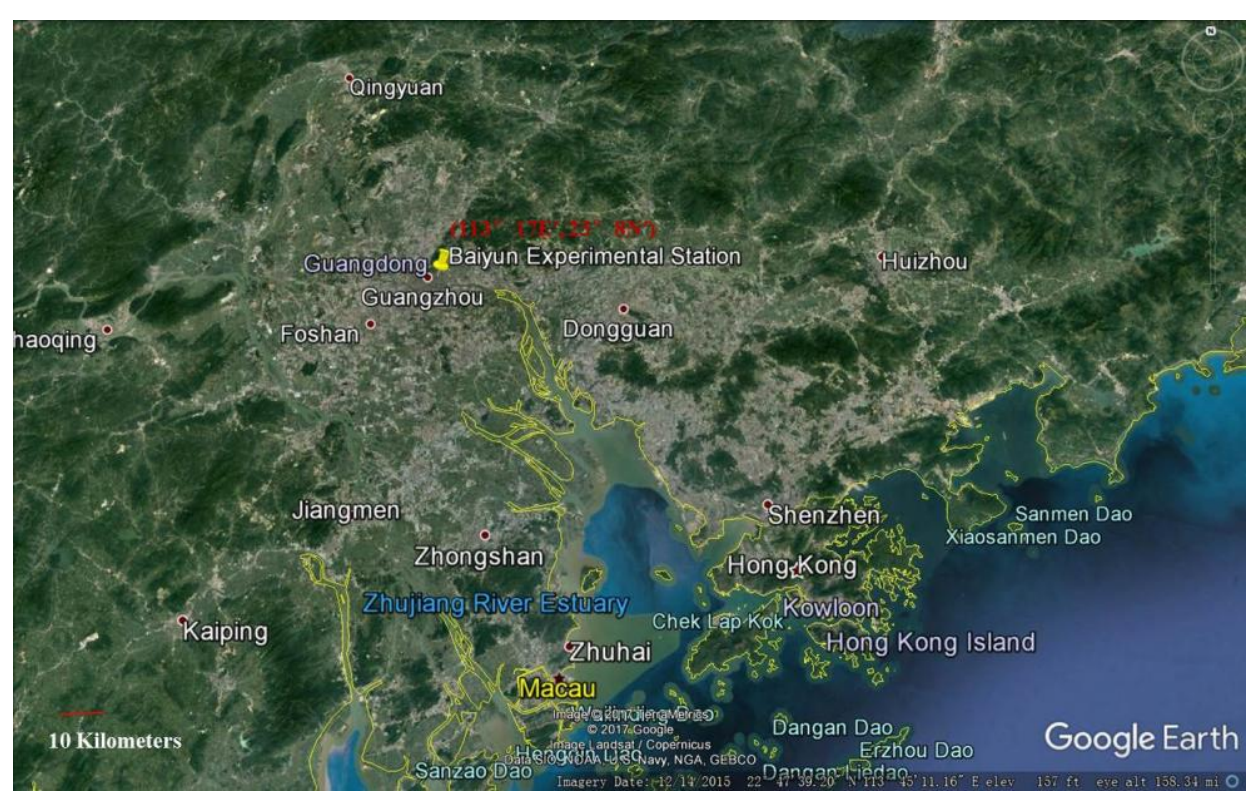

Figure 1. GPS coordinates of the experimental site. The image is generated by the software of Google Earth 
Table 2. The key information of planting seeds and the management of potato in the experiment

\begin{tabular}{c|c|c}
\hline Items & $\mathbf{2 0 1 3}$ to 2014 & $\mathbf{2 0 1 4}$ to 2015 \\
\hline Potato cultivar & Yueyin85-38 \\
Farmyard manure & $75 \mathrm{tha}^{-1}$ \\
Fertilizer & One-time application, fertilizer containing nitrogen $\left(285 \mathrm{~kg} \mathrm{ha}^{-1}\right)$, \\
Planting mode & $\mathrm{P}_{2} \mathrm{O}_{5}\left(225 \mathrm{~kg} \mathrm{ha}^{-1}\right)$ and potassium $\left(450 \mathrm{~kg} \mathrm{ha}^{-1}\right)$ \\
Sowing depth & Ridges with two rows \\
Sowing date & $10 \mathrm{~cm}$ \\
plant protection & Nov. 20, 2013 Nov. 27, 2014 \\
Hilling & at 50 days and 60 days after emergence \\
Irrigation frequencies & Hilling twice, after emergence and at tillering stage \\
Weed control & Furrow irrigation once a month
\end{tabular}

\section{Plant sampling}

The emergence rate, emergence date and duration were recorded when $75 \%$ plants had acquired the characteristics of the stage under each treatment. The roots and shoots of three plants per treatment were measured to determine the fresh weight and were then oven-dried at $105^{\circ} \mathrm{C}$ for $48 \mathrm{~h}$ to determine the dry weight (Wang et al., 2005). After harvesting, ten plants in each treatment were randomly sampled for the indoor test, and the tubers were divided manually into two grades, greater than and less than $50 \mathrm{~g}$ fresh weight.

\section{Soil properties analysis}

In two growing seasons, three soil samples were taken randomly from the surface to a soil depth of $5 \mathrm{~cm}$ in each treatment before sowing and after harvesting. The soil's available nitrogen, phosphorus and potassium were detected. Soil available nitrogen includes ammonium and nitrate forms of nitrogen. In diffusion dishes containing ferrous sulphate, the soil was hydrolysed and reduced under a strong alkaline environment. Nitrogen in the soil was converted into ammonia and then absorbed by a boric acid solution. The absorbed liquid ammonia was titrated with sulfuric acid, and the available nitrogen content was calculated based on the amount of the sulfuric acid (Duan et al., 2007). Soil available potassium was extracted by $1 \mathrm{~mol} / \mathrm{L}$ acetic acid ammonium and then measured by a flame photometer (Du et al., 2004). Soil available phosphorus was extracted by a solution of $0.05 \mathrm{~mol} / \mathrm{L} \mathrm{HCl}$ and $0.025 \mathrm{~mol} / \mathrm{L} \mathrm{H}_{2} \mathrm{SO}_{4}$ and then measured by a spectrophotometer (Jiao et al., 2015).

\section{Soil microorganism analysis}

In two growing seasons, three soil samples were taken randomly from the surface to a soil depth of $5 \mathrm{~cm}$ in each treatment before sowing and after harvesting. Counts of total bacteria were measured on $10^{-5}$ and $10^{-4}$ nutrient agar medium $\left(5 \mathrm{gL}^{-1}\right.$ peptone, 3 $\mathrm{gL}^{-1}$ beef extract, $1 \mathrm{gL}^{-1}$ yeast extract, $15 \mathrm{gL}^{-1}$ agar, $5 \mathrm{gL}^{-1}$ glucose) (Wollum, 1982) counts of total actinomycetes were measured on $10^{-4}$ and $10^{-3}$ Gauserime synthetic agar medium (20 gL $\mathrm{gL}^{-1}$ Soluble Starch, $0.5 \mathrm{gL}^{-1} \mathrm{NaCI}, 1 \mathrm{gL}^{-1} \mathrm{KNO}_{3}, 0.5 \mathrm{gL}^{-1} \mathrm{~K}_{2} \mathrm{HPO}_{4} \cdot 3 \mathrm{H}_{2} \mathrm{O}$, 
$0.5 \mathrm{gL}^{-1} \mathrm{MgSO}_{4} .7 \mathrm{H}_{2} \mathrm{O}, 0.01 \mathrm{gL}^{-1} \mathrm{FeSO}_{4} .7 \mathrm{H}_{2} \mathrm{O}, 15 \mathrm{gL}^{-1}$ agar, $\left.\mathrm{pH} 7.4\right)$, and total fungi were measured on Martin's Rose Bengal agar medium $\left(5 \mathrm{gL}^{-1}\right.$ peptone, $10 \mathrm{gL}^{-1}$ glucose, $1 \mathrm{gL}^{-1} \mathrm{KH}_{2} \mathrm{SO}_{4}, 0.5 \mathrm{gL}^{-1} \mathrm{MgSO}_{4}, 0.01 \mathrm{gL}^{-1}$ rose bengal sodium, $14 \mathrm{gL}^{-1}$ agar, $\mathrm{pH}$ 6.0) (Martin, 1950). The plates were incubated in darkness at $25^{\circ} \mathrm{C}$ for 3 to $4 \mathrm{~d}$ for the bacteria, $10 \mathrm{~d}$ for the fungi and $7 \mathrm{~d}$ for the actinomycetes.

\section{Statistical analysis}

The One-Way ANOVA procedure in SPSS Statistics 17.0 was used to conduct analysis of variance. Mean values of the treatments were compared using the Duncan test at $p \leq 0.05$. Mean values are reported in Tables 3, 5, 6, 7, 8 and Figure 5.

\section{Results}

\section{Air and soil temperature}

In the growing season from October 2013 to April 2014, the mean monthly air temperature ranged from $13.0^{\circ} \mathrm{C}$ to $24.0^{\circ} \mathrm{C}$, averaging $17.3^{\circ} \mathrm{C}$, monthly maximum air temperature was in the range of $18.0^{\circ} \mathrm{C} \sim 29.0^{\circ} \mathrm{C}$ and the monthly minimum air temperature was in the range of $8.0^{\circ} \mathrm{C} \sim 19.0^{\circ} \mathrm{C}$. There were 60 days had a daily minimum temperature lower than $15.0^{\circ} \mathrm{C}$, mainly concentrated in the December to February, and extreme low temperature was $3.0^{\circ} \mathrm{C}$ (Fig. $2 a$ ). In the growing season from October 2014 to April 2015, the mean monthly air temperature ranged from $13.0^{\circ} \mathrm{C}$ to $25.0^{\circ} \mathrm{C}$, averaging $18.3^{\circ} \mathrm{C}$, monthly maximum air temperature was in the range of $17.0^{\circ} \mathrm{C}$ to $30.0^{\circ} \mathrm{C}$ and the minimum air temperature was in the range of $9.0^{\circ} \mathrm{C}$ to $20.0^{\circ} \mathrm{C}$. There were 63 days had a daily minimum temperature lower than $15.0^{\circ} \mathrm{C}$, mainly concentrated in the December to February, and extreme low temperature was $4.0^{\circ} \mathrm{C}$ (Fig. 2b).
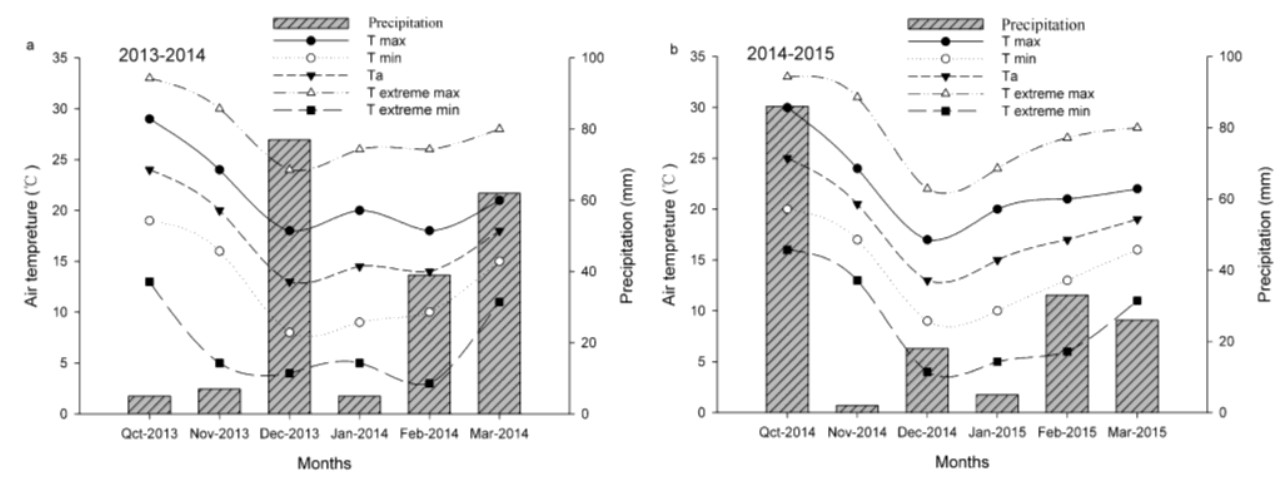

Figure 2. Average monthly air temperature and precipitation during the potato growing season in 2013 2014 and 2014 2015. T max: maximum average monthly air temperature; T min: minimum average monthly air temperature; Ta: average monthly air temperature. T extreme max: extreme maximum average monthly air temperature; T extreme min: extreme minimum average monthly air temperature

During the growing season from October 2014 to February 2015, the daily mean soil temperature in different depths under black and white plastic mulch were higher $0^{\circ} \mathrm{C} \sim 7.5^{\circ} \mathrm{C}, 0^{\circ} \mathrm{C} \sim 6.5^{\circ} \mathrm{C}$ compared with that in bare soil, respectively (Fig. 3a, 3b). 
However, rice straw mulch mainly decreased soil temperature, the temperature differences in different depths between rice straw mulch and bare soil was $2.5^{\circ} \mathrm{C} \sim 1.0^{\circ} \mathrm{C}$ (Fig. 3c). At the early growing season, daily mean soil temperature under black and white plastic mulch were higher $1.0 \sim 7.5^{\circ} \mathrm{C}, 1.0 \sim 6.5^{\circ} \mathrm{C}$ than that in bare soil (Fig. 3a, 3b), but the soil temperature under rice straw was close to or even lower than bare soil, the temperature differences in different depths between rice straw mulch and bare soil was $-2.5^{\circ} \mathrm{C} \sim 1.0^{\circ} \mathrm{C}$ (Fig. 3c). In the middle growing season, as the plant canopy enlarged, the soil surface was shaded, the soil temperature differences between mulch and non-mulch became smaller, $0 \sim 4.3^{\circ} \mathrm{C}$ for black plastic mulch, $0 \sim 3.5^{\circ} \mathrm{C}$ for white plastic mulch, $-1 \sim 0.67^{\circ} \mathrm{C}$ for rice straw mulch (Fig. 3a-c). In the late growing days, the plant leaves senescent and dropped, the soil temperature increasing again, black and white plastic mulch also showed small soil temperature differences compared with that in bare soil, $0.8 \sim 2.0^{\circ} \mathrm{C}$ and $0 \sim 2.2^{\circ} \mathrm{C}$, respectively (Fig. $3 a, 3 b)$. And the differences between rice straw mulch and bare soil was even more smaller, $-0.83^{\circ} \mathrm{C} \sim 0.83^{\circ} \mathrm{C}$ (Fig. 3c).
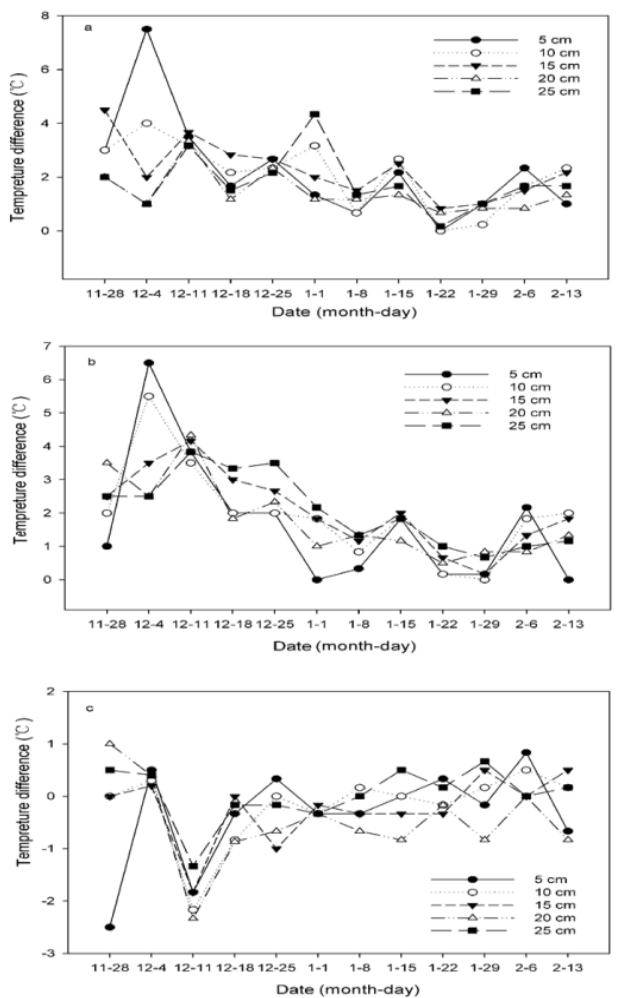

Figure 3. Differences in daily mean soil temperature at different soil depths under mulch and no-mulch conditions. a: black plastic mulch; $b$ : white plastic mulch; $c$ : rice straw mulch

\section{Emergence rate and growth stages duration}

Due to the favourable changes in soil temperature by mulching, the emergence rate was increased by $16.2 \%, 14.9 \%$ and $11.0 \%$ under black, white and rice straw mulch, respectively in the winter of 2013. Similarly, in 2014 winter, the emergence rate was improved by $14.0 \%, 14.2 \%$ and $10.4 \%$ under black, white and rice straw mulch, respectively (Table 3). 
Table 3. Emergence rate of potato under different mulching conditions in 2013 2014 and 2014 2015

\begin{tabular}{c|c|c|c|c}
\hline \multirow{2}{*}{ Treatments } & \multicolumn{2}{|c|}{ Emergence rate (\%) } & \multicolumn{2}{c}{ Increasing in emergence rate (\%) } \\
\cline { 2 - 5 } & $\mathbf{2 0 1 3 - 2 0 1 4}$ & $\mathbf{2 0 1 4 - 2 0 1 5}$ & $\mathbf{2 0 1 3 - 2 0 1 4}$ & $\mathbf{2 0 1 4 - 2 0 1 5}$ \\
\hline Black plastic mulch & $88.7 \mathrm{a}$ & $90.1 \mathrm{a}$ & 16.2 & 14.0 \\
White plastic mulch & $87.1 \mathrm{a}$ & $90.4 \mathrm{a}$ & 14.9 & 14.2 \\
Rice straw mulch & $83.4 \mathrm{a}$ & $86.5 \mathrm{~b}$ & 11.0 & 10.4 \\
Bare soil & $72.2 \mathrm{~b}$ & $75.6 \mathrm{c}$ & -- & -- \\
\hline
\end{tabular}

Means within columns followed by different lower-case letters $(a, b, c)$ stand for significance different at $\mathrm{p} \leq 0.05$

Besides increasing the emergence rate, the emergence also been accelerated by mulch. Compared to bare soil, emergence was $10 \mathrm{~d}, 8 \mathrm{~d}$ and $1 \mathrm{~d}$ earlier in 2013 growing season and $7 \mathrm{~d}, 4 \mathrm{~d}$ and $1 \mathrm{~d}$ earlier in 2014 growing season under black, white and rice straw mulch, respectively (Table 4). And due to the early emergence, the corresponding maturation periods were less $4 \mathrm{~d}, 9 \mathrm{~d}$ and $1 \mathrm{~d}$ in 2013 growing season and $4 \mathrm{~d}, 11 \mathrm{~d}$ and $1 \mathrm{~d}$ in 2014 growing season under black, white and rice straw mulch, respectively (Table 4, Fig. 4).

Table 4. The date of sowing, emergence and maturing under different mulch conditions in 2013 to 2014 and 2014 to 2015 growing seasons

\begin{tabular}{|c|c|c|c|c|c|c|}
\hline & \multicolumn{3}{|c|}{ 2013-2014 } & \multicolumn{3}{|c|}{ 2014-2015 } \\
\hline & $\begin{array}{c}\text { Sowing } \\
2013\end{array}$ & $\begin{array}{c}\text { Emergence } \\
2013\end{array}$ & $\begin{array}{c}\text { Maturing } \\
2014\end{array}$ & $\begin{array}{c}\text { Sowing } \\
2014\end{array}$ & $\begin{array}{c}\text { Emergence } \\
2014\end{array}$ & Maturing \\
\hline $\begin{array}{l}\text { Black plastic } \\
\text { mulch }\end{array}$ & Nov.26 & Dec.18 (22b) & Mar.29 (123b) & Nov. 20 & Dec.6 (16b) & Mar.16 (116b) \\
\hline $\begin{array}{c}\text { White plastic } \\
\text { mulch }\end{array}$ & Nov.26 & Dec.20 (24b) & Mar.23 (117c) & Nov. 20 & Dec.9 (19b) & Mar.9 (109c) \\
\hline Rice straw mulch & Nov.26 & Dec.26 (30a) & Apr.1 (126a) & Nov.20 & Dec.15 (25a) & Mar.19 (119a) \\
\hline Bare soil & Nov.26 & Dec.28 (32a) & Apr.2 (127a) & Nov.20 & Dec.13 (23a) & Mar.20 (120a) \\
\hline
\end{tabular}

The numbers in parentheses indicate the duration days, and means within columns followed by different lower-case letters $(\mathrm{a}, \mathrm{b}, \mathrm{c})$ stand for significance different at $\mathrm{p} \leq 0.05$

\section{Biomass accumulation}

Aboveground fresh and dry weight increased gradually during the growing season in 2014. At the $30 \mathrm{~d}$ after sowing, the plants under black and white plastic mulch showed significantly higher accumulation $(\mathrm{p}<0.05)$ both in fresh and dry weight compared with rice straw treatment and bare soil. At the $45 \mathrm{~d}$ after sowing, the plants under only black plastic mulch showed significantly higher accumulation of fresh and dry weight. During the middle growing period, no difference was observed among the treatments. And at the late growing days, the black plastic treatment showed much higher aboveground fresh and dry weight (Fig. 5a, 5b). Under-ground fresh and dry weight increased rapidly during the growing season in 2014. At the early growing days, there was no significant difference among the treatments. However, the black plastic mulch showed highest fresh and dry weight from $75 \mathrm{~d}$ to $105 \mathrm{~d}$ after sowing, and significant difference 
were found for dry weight at 90 and $105 \mathrm{~d}$ after sowing (Fig. 5c, 5d). Tuber biomass showed the same tendency with under-ground biomass, which the black plastic treatment have the highest fresh and dry weight in the later growing period, and significant differences were found for tuber dry weight at 90 and $105 \mathrm{~d}$ after sowing (Fig. 5e, 5f).
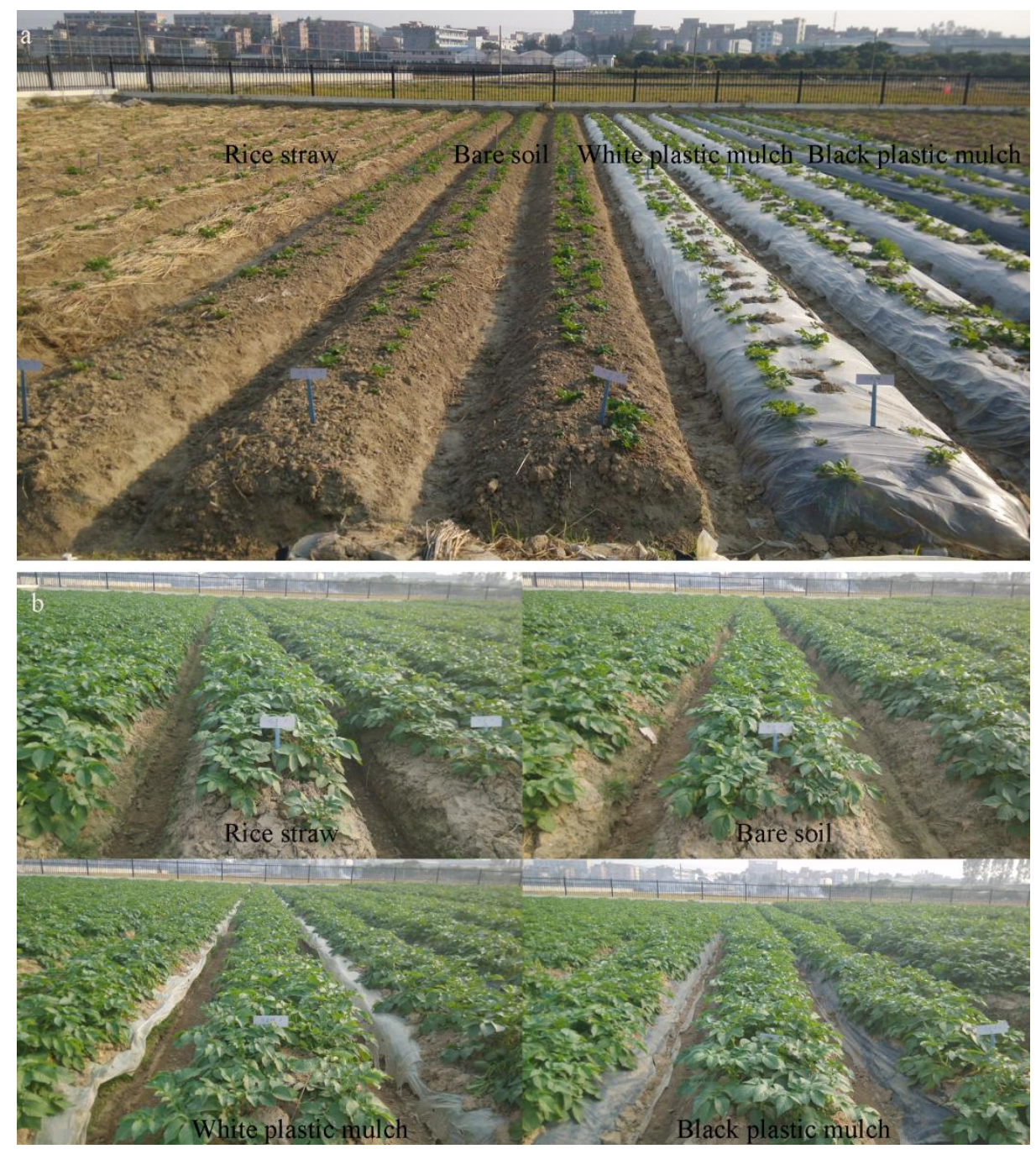

Figure 4. Potato field performance in 2014 to 2015 growing seasons. a: the photo was taken on 16 December, 2014; $b$ : the photo was taken on 26 January, 2015

\section{Tuber size and yield}

Based on weight, tubers were divided into two grades: small tubers $(<50 \mathrm{~g})$ and large tubers $(\geq 50 \mathrm{~g})$. In 2013 2014, the black plastic mulch treatments had the greatest weight and number of large tubers, and then followed by the rice straw mulch and bare soil; the white plastic mulch is the lowest. While, with respect to small tubers, the white plastic mulch treatment showed significantly heavier and much more number of small tubers than other mulch treatments and bare soil $(\mathrm{p} \leq 0.05)$. Thus, the tuber numbers and weight were significantly higher in the black mulch than other treatment and bare soil $(\mathrm{p} \leq 0.05)$ (Table 5). 

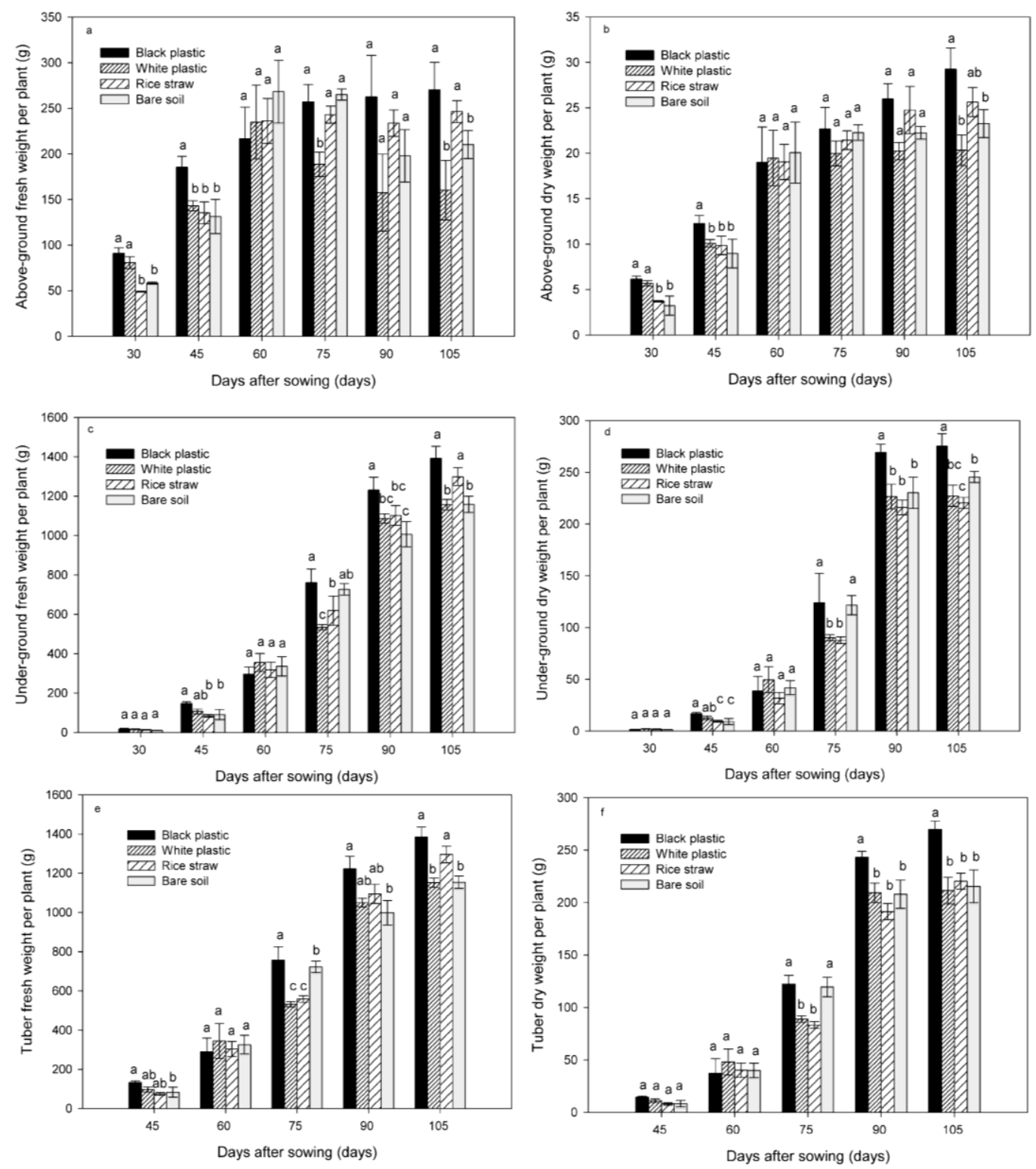

Figure 5. Above-ground and under-ground biomass under different mulch conditions. a: aboveground fresh weight per plant; $b$ : above-ground dry weight per plant; $c$ : under-ground fresh weight per plant; $d$ : under-ground dry weight per plant; $e:$ tuber fresh weight per plant; $f:$ tuber dry weight per plant. Means within columns followed by different lower-case letters $(a, b, c)$ stand for significance different at $p \leq 0.05$

In 2014 2015, the rice straw mulch treatment had the greatest number of large tubers, which was significant different with white plastic mulch $(\mathrm{p} \leq 0.05)$, but no significant difference with black plastic mulch and bare soil. The black plastic mulch had the greatest weight of large tubers, which was significant different with white plastic mulch $(\mathrm{p} \leq 0.05)$, but no significant difference between black plastic mulch and bare soil. Although, the white plastic mulch treatment showed the greatest weight and number of small tubers, there were no significant difference among the three mulch treatments and bare soil. In total tuber number and weight, there were no significant differences among all the treatments $(\mathrm{p} \leq 0.05)$ (Table 5). 
Table 5. Potato tuber grades and weight of ten sample plants under different mulching conditions in 2013 2014 and 2014 2015 growing seasons

\begin{tabular}{|c|c|c|c|c|c|c|}
\hline & \multicolumn{3}{|c|}{ Tuber numbers of ten plants } & \multicolumn{3}{|c|}{ Tuber weight of ten plants } \\
\hline & $\mathrm{W} \geq \mathbf{5 0} \mathrm{g}$ & $\mathrm{W}<50 \mathrm{~g}$ & Total & $\mathrm{W} \geq 50 \mathrm{~g}$ & $\mathrm{~W}<50 \mathrm{~g}$ & Total \\
\hline \multicolumn{7}{|l|}{ 2013-2014 } \\
\hline $\begin{array}{l}\text { Black plastic } \\
\text { mulch }\end{array}$ & $42.67 \pm 2.86 \mathrm{a}$ & $22.32 \pm 1.01 \mathrm{ab}$ & $64.17 \pm 2.21 \mathrm{a}$ & $5.57 \pm 0.29 a$ & $0.63 \pm 0.12 \mathrm{ab}$ & $6.20 \pm 0.24 \mathrm{a}$ \\
\hline $\begin{array}{c}\text { White plastic } \\
\text { mulch }\end{array}$ & $29.33 \pm 3.63 c$ & $25.33 \pm 2.67 \mathrm{a}$ & $50.83 \pm 1.67 b$ & $3.83 \pm 1.11 \mathrm{c}$ & $0.71 \pm 0.11 \mathrm{a}$ & $3.87 \pm 0.58 b$ \\
\hline $\begin{array}{l}\text { Rice straw } \\
\text { mulch }\end{array}$ & $39.33 \pm 5.76 \mathrm{ab}$ & $15.00 \pm 2.89 b$ & $50.83 \pm 5.46 b$ & $4.60 \pm 0.27 \mathrm{ab}$ & $0.33 \pm 0.06 b$ & $4.93 \pm 0.31 b$ \\
\hline Bare soil & $33.67 \pm 2.86 b c$ & $17.67 \pm 1.45 \mathrm{ab}$ & $50.83 \pm 3.00 \mathrm{~b}$ & $4.20 \pm 0.16 b c$ & $0.67 \pm 0.09 \mathrm{a}$ & $4.87 \pm 0.15 b$ \\
\hline \multicolumn{7}{|l|}{ 2014-2015 } \\
\hline $\begin{array}{l}\text { Black plastic } \\
\text { mulch }\end{array}$ & $42.67 \pm 2.27 \mathrm{ab}$ & $7.33 \pm 2.33 \mathrm{a}$ & $50.00 \pm 3.78 \mathrm{a}$ & $8.32 \pm 0.59 \mathrm{a}$ & $0.24 \pm 0.10 \mathrm{a}$ & $8.47 \pm 0.57 \mathrm{a}$ \\
\hline $\begin{array}{c}\text { White plastic } \\
\text { mulch }\end{array}$ & $39.02 \pm 3.67 \mathrm{~b}$ & $10.00 \pm 3.06 \mathrm{a}$ & $49.00 \pm 5.51 \mathrm{a}$ & $6.91 \pm 0.39 b$ & $0.34 \pm 0.17 \mathrm{a}$ & $7.31 \pm 0.51 \mathrm{a}$ \\
\hline $\begin{array}{l}\text { Rice straw } \\
\text { mulch }\end{array}$ & $48.33 \pm 2.86 \mathrm{a}$ & $7.33 \pm 2.09 \mathrm{a}$ & $55.67 \pm 3.84 a$ & $7.96 \pm 0.17 \mathrm{ab}$ & $0.22 \pm 0.10 \mathrm{a}$ & $8.21 \pm 0.23 \mathrm{a}$ \\
\hline Bare soil & $48.21 \pm 3.74 \mathrm{ab}$ & $5.00 \pm 2.64 \mathrm{a}$ & $54.67 \pm 3.28 \mathrm{a}$ & $8.08 \pm 0.39 \mathrm{ab}$ & $0.12 \pm 0.09 \mathrm{a}$ & $7.87 \pm 0.05 \mathrm{a}$ \\
\hline
\end{tabular}

W: weight per tuber

The values indicate means \pm standard deviation of ten biological replicates, and means within same columns followed by different lower-case letters $(a, b, c)$ stand for significance different at $\mathrm{p} \leq 0.05$

The highest tuber yields for the two growing season were observed in the black mulch treatment, which was $21.5 \%$ and $12.0 \%$ higher than bare soil in 2013 2014 and 2014 2015 respectively. And then followed by rice straw mulch, 9.4\% and $8.0 \%$ higher than bare soil in 2013 2014 and 2014 2015 respectively, the lowest tuber yield was obtained in the white plastic mulch treatment, $7.5 \%$ and $4.0 \%$ lower than bare soil in 2013 2014 and 2014 2015, respectively (Table 6).

Table 6. Yields of potato under different mulch conditions in 2013 2014 and 2014 2015 growing seasons

\begin{tabular}{c|c|c|c|c|c|c|c|c}
\hline \multirow{2}{*}{ Treatments } & \multicolumn{4}{|c|}{ 2013 2014 } & \multicolumn{3}{c}{ 2014 2015 } \\
\cline { 2 - 8 } & $\begin{array}{c}\text { Black } \\
\text { plastic }\end{array}$ & $\begin{array}{c}\text { White } \\
\text { plastic }\end{array}$ & $\begin{array}{c}\text { Rice } \\
\text { straw }\end{array}$ & Bare soil & $\begin{array}{c}\text { Black } \\
\text { plastic }\end{array}$ & $\begin{array}{c}\text { White } \\
\text { plastic }\end{array}$ & $\begin{array}{c}\text { Rice } \\
\text { straw }\end{array}$ & Bare soil \\
\hline Yield $\left(\mathrm{kg} \mathrm{ha}^{-1}\right)$ & $2790.3 \mathrm{a}$ & $2043.6 \mathrm{~b}$ & $2418.5 \mathrm{~b}$ & $2191.5 \mathrm{~b}$ & $3852.2 \mathrm{a}$ & $3262.5 \mathrm{~b}$ & $3681.8 \mathrm{a}$ & $3390.2 \mathrm{~b}$ \\
$\begin{array}{c}\text { Increasing in } \\
\text { yield (\%) }\end{array}$ & 21.5 & -7.2 & 9.4 & - & 12.0 & -4.0 & 8.0 & - \\
\hline
\end{tabular}

The increasing in yield (\%) was compared with the bare soil treatment Means within columns followed by different lower-case letters $(a, b, c)$ stand for significance different at $\mathrm{p} \leq 0.05$ 


\section{Soil fertility properties}

The soil fertility properties were measured before sowing and after harvest in each season. Higher contents of available nitrogen, potassium and phosphorus were recorded after harvest both in mulch and non-mulch treatments compared with before sowing. In both growing seasons, the content of available nitrogen $(\mathrm{N})$ was increased significantly $(\mathrm{p} \leq 0.05)$ higher in rice straw mulch compared with that in bare soil, increased by $1.14 \%$ and $1.10 \%$, respectively, and lowest content of available $\mathrm{N}$ were found in black and white plastic mulch treatments. In 2013 2014 growing season, the content of available phosphorus $(\mathrm{P})$ was increased most in black and white mulch, then in rice straw mulch, bare soil was the lowest. However, in 2014 2015 growing season the content of available $\mathrm{P}$ was increased most in white mulch and bare soil, then in black plastic mulch, rice straw mulch was the lowest. With respect to content of available potassium (K), in 2013 2014 growing season, black plastic, white plastic and rice straw mulch showed significantly higher content of available K compared with that in bare soil. While in 2014 2015 growing season, black plastic mulch, rice straw mulch and bare soil showed significantly higher content of available K compared with that in bare soil (Table 7).

Table 7. The contents of available N, $P, K$ under different mulch conditions in 2013 2014 and 2014 2015 growing seasons

\begin{tabular}{c|c|c|c|c|c|c|c|c|c}
\hline & \multicolumn{2}{|c|}{ Available N (mg/kg) } & \multicolumn{2}{c|}{ Available P (mg/kg) } & \multicolumn{3}{c}{ Available K (mg/kg) } \\
\cline { 2 - 9 } Treatments & $\begin{array}{c}\text { Before } \\
\text { Sowing }\end{array}$ & $\begin{array}{c}\text { After } \\
\text { harvest }\end{array}$ & $\begin{array}{c}\text { Increase } \\
\text { in yield } \\
(\%)\end{array}$ & $\begin{array}{c}\text { Before } \\
\text { sowing }\end{array}$ & $\begin{array}{c}\text { After } \\
\text { harvest }\end{array}$ & $\begin{array}{c}\text { Increase } \\
\text { in yield } \\
(\%)\end{array}$ & $\begin{array}{c}\text { Before } \\
\text { sowing }\end{array}$ & $\begin{array}{c}\text { After } \\
\text { harvest }\end{array}$ & $\begin{array}{c}\text { Increase } \\
\text { in yield } \\
(\%)\end{array}$ \\
\hline $2013 \sim 2014$ & & & & & & & & & \\
Black plastic & 83.95 & 124.95 & $0.49 \mathrm{c}$ & 25.11 & 38.15 & $0.52 \mathrm{a}$ & 60.00 & 101.50 & $0.7 \mathrm{a}$ \\
White plastic & 88.37 & 117.48 & $0.33 \mathrm{c}$ & 27.95 & 43.12 & $0.54 \mathrm{a}$ & 64.00 & 102.50 & $0.60 \mathrm{~b}$ \\
Rice straw & 79.53 & 170.09 & $1.14 \mathrm{~b}$ & 24.29 & 34.34 & $0.41 \mathrm{ab}$ & 58.00 & 93.00 & $0.60 \mathrm{~b}$ \\
Bare soil & 89.47 & 143.60 & $0.60 \mathrm{~b}$ & 25.51 & 33.85 & $0.33 \mathrm{~b}$ & 66.00 & 88.00 & $0.33 \mathrm{~b}$ \\
2014 2015 & & & & & & & & & \\
Black plastic & 66.37 & 92.27 & $0.39 \mathrm{c}$ & 55.61 & 76.78 & $0.38 \mathrm{a}$ & 95.00 & 140.00 & $0.47 \mathrm{a}$ \\
White plastic & 64.52 & 92.27 & $0.43 \mathrm{c}$ & 59.67 & 87.81 & $0.47 \mathrm{a}$ & 93.50 & 122.50 & $0.31 \mathrm{~b}$ \\
Rice straw & 67.11 & 141.10 & $1.10 \mathrm{a}$ & 64.17 & 81.73 & $0.27 \mathrm{~b}$ & 90.00 & 142.50 & $0.58 \mathrm{a}$ \\
Bare soil & 63.41 & 108.17 & $0.71 \mathrm{~b}$ & 51.33 & 76.33 & $0.49 \mathrm{a}$ & 90.00 & 135.00 & $0.50 \mathrm{a}$ \\
\hline
\end{tabular}

The numbers in parentheses indicate the duration days, and means within columns followed by different lower-case letters $(\mathrm{a}, \mathrm{b}, \mathrm{c})$ stand for significance different at $\mathrm{p} \leq 0.05$

\section{Soil microorganism}

\section{Total bacteria}

Counts of total bacteria were increased after harvest both in mulch and non-mulch treatments in two growing season. In 2013, the rice straw mulch showed highest growth of total bacteria amount, and the white plastic mulch is the lowest. But no such difference was apparent in 2014, the highest growth of total bacteria amount was found in black plastic mulch, and lowest was in bare soil plot (Table 8). 


\section{Total fungi}

Counts of total fungi were reduced after harvest both in mulch and non-mulch treatments in two growing seasons and showed same tendency. The largest reduction of total fungi amount was observed in white plastic mulch and smallest reduction was found in rice straw mulch (Table 8).

\section{Total actinomycetes}

Counts of total actinomycetes were also reduced after harvest both in mulch and nonmulch treatments in two growing seasons. Significantly reduction was obtained in bare soil in 2013 2014 and in white plastic mulch in 2014 2015, no significantly difference in counts of total actinomycetes was found in other treatments (Table 8).

Table 8. Soil microorganisms evaluated under different mulch conditions in 2013 2014 and 2014 2015 growing seasons

\begin{tabular}{|c|c|c|c|c|c|c|}
\hline & \multicolumn{3}{|c|}{$2013 \sim 2014$} & \multicolumn{3}{|c|}{$2014 \sim 2015$} \\
\hline & Before sowing & After harvest & $\begin{array}{c}\text { Increased by } \\
(\%)\end{array}$ & $\begin{array}{l}\text { Before } \\
\text { sowing }\end{array}$ & After harvest & $\begin{array}{c}\text { Increased by } \\
(\%)\end{array}$ \\
\hline & \multicolumn{3}{|c|}{ Total bacteria $\left(* 10^{5} \mathrm{CFU} \mathrm{g}^{-1}\right.$ dry soil $)$} & \multicolumn{3}{|c|}{ Total bacteria $\left(* 10^{5} \mathrm{CFU} \mathrm{g}^{-1}\right.$ dry soil $)$} \\
\hline Black plastic & 164 & $\mid 196$ & $0.20 \mathrm{~b}$ & 123 & 458 & $2.72 \mathrm{a}$ \\
\hline White plastic & 372 & 423 & $0.14 \mathrm{~b}$ & 137 & 426 & $2.11 \mathrm{~b}$ \\
\hline Rice straw & 358 & 632 & $0.77 \mathrm{a}$ & 135 & 381 & $1.82 \mathrm{~b}$ \\
\hline \multirow[t]{2}{*}{ Bare soil } & 275 & 348 & $0.27 \mathrm{~b}$ & 105 & 237 & $1.26 \mathrm{c}$ \\
\hline & \multicolumn{3}{|c|}{ Total fungi $\left(* 10^{3} \mathrm{CFU} \mathrm{g}^{-1}\right.$ dry soil $)$} & \multicolumn{3}{|c|}{ Total fungi $\left(* 10^{3} \mathrm{CFU} \mathrm{g}^{-1}\right.$ dry soil $)$} \\
\hline Black plastic & 133 & 41 & $0.69 \mathrm{ab}$ & 119 & 63 & $0.47 \mathrm{ab}$ \\
\hline White plastic & 321 & 40 & $0.88 \mathrm{a}$ & 120 & 34 & $0.72 \mathrm{a}$ \\
\hline Rice straw & 230 & 164 & $0.28 b$ & 125 & 84 & $0.328 b$ \\
\hline \multirow[t]{2}{*}{ Bare soil } & 258 & 121 & $0.53 \mathrm{ab}$ & 110 & 44 & $0.6 \mathrm{ab}$ \\
\hline & \multicolumn{3}{|c|}{ Total actinomycetes $\left(* 10^{5} \mathrm{CFU} \mathrm{g}^{-1}\right.$ dry soil $)$} & \multicolumn{3}{|c|}{ Total actinomycetes $\left(* 10^{5} \mathrm{CFU} \mathrm{g}^{-1}\right.$ dry soil) } \\
\hline Black plastic & 22 & 12 & $0.45 \mathrm{ab}$ & 132 & 101 & $0.23 \mathrm{~b}$ \\
\hline White plastic & 55 & 40 & $0.27 \mathrm{~b}$ & 109 & 63 & $0.42 \mathrm{a}$ \\
\hline Rice straw & 31 & 22 & $0.29 b$ & 88 & 60 & $0.32 \mathrm{ab}$ \\
\hline Bare soil & 39 & 16 & $0.59 \mathrm{a}$ & 124 & 82 & $0.34 \mathrm{ab}$ \\
\hline
\end{tabular}

CFU: colony-forming unit. Data represents three replicates, and means within columns followed by different lowercase letters $(a, b, c)$ stand for significance different at $\mathrm{p} \leq 0.05$

\section{Discussion}

Unlike in northern China, where potato is planted in June and harvested in October, in southern China, the potato growing season is from November to next year's April, and the limiting factor is low temperatures below $15^{\circ} \mathrm{C}$, especially in the early growing days of December and January. There were more than $40 \mathrm{~d}$ with mean temperatures below $15^{\circ} \mathrm{C}$ (Fig. 2). According to our research, the daily mean temperature was $0^{\circ} \mathrm{C}$ to $7.5^{\circ} \mathrm{C}$ and $0^{\circ} \mathrm{C}$ to $6.5^{\circ} \mathrm{C}$ higher under black and white plastic mulch than under nonmulch conditions (Fig. 3). Thus, mulching is an effective method to increase the topsoil's temperature. Because of the favourable changes in soil temperature caused by mulching, the emergence rate increased and the emergence date was accelerated (Tables 3 , 4). Above-ground fresh and dry weights increased gradually during the growing season in 2014. At $30 \mathrm{~d}$ after sowing, the plants under black and white plastic mulch 
showed significantly higher accumulations both in fresh and dry weights compared with those of the rice straw treatment and bare soil. At $45 \mathrm{~d}$ after sowing, only the plants under black plastic mulch showed significantly higher accumulations of fresh and dry weights (Fig. 5a, 5b). Under-ground fresh and dry weights increased rapidly during the growing season in 2014, the black plastic mulch showed the greatest fresh and dry weights from $75 \mathrm{~d}$ to $105 \mathrm{~d}$ after sowing, and significant differences were found for dry weights at $90 \mathrm{~d}$ and $105 \mathrm{~d}$ after sowing (Fig. 5c, 5d). The tuber biomass showed the same tendency as the under-ground biomass, with the black plastic treatment having the greatest fresh and dry weights in the later growing period, and significant differences were found among tuber dry weights at 90 and $105 \mathrm{~d}$ after sowing (Fig. 5e, 5f). The tuber numbers and weights were significantly greater under the black mulch than under the other treatments and bare soil (Table 5), the greatest tuber yields for the two growing season were observed under the black mulch treatment, and they were $21.5 \%$ and $12.0 \%$ greater than in bare soil in 2013 to 2014 and 2014 to 2015, respectively (Table 6). Higher soil temperatures with the plastic mulch were also observed in other reports (Baghour et al., 2002; Ramakrishna et al., 2006; Wang et al., 2009; Hou et al., 2010; Ibarra-Jiménez et al., 2011; Dvořák et al., 2012; Zhao et al., 2012), and for other crops, such as maize (Liu et al., 2009; Zhou et al., 2012), tomatillo (Díaz-Pérez et al., 2005), broccoli (Díaz-Pérez, 2009), tomato (Díaz, 2002), and spring wheat (Li et al., 1999; 2004). However, increasing the soil temperature can harm potato production, especially in regions with enough or excess heat. For instance, the highest daily soil temperatures at $5 \mathrm{~cm}$ and $10 \mathrm{~cm}$ depths were above $30^{\circ} \mathrm{C}$ during the period from early May to late June, which is detrimental to potato tuber initiation and bulking (Wang et al., 2009). Thus, the excessive heat generated by the plastic film is mostly responsible for the lower yields, and similar results have been demonstrated (Baghour et al., 2002; Wang et al., 2009; Hou et al., 2010; Zhao et al., 2012).

Rice straw mulch has also been widely employed because it is convenient and cost efficient. The soil temperature under rice straw was close to or even lower than bare soil only, and the temperature differences at different depths between rice straw mulch and bare soil were $-2.5^{\circ} \mathrm{C}$ to $1.0^{\circ} \mathrm{C}$ (Fig. 3). Similar results were also found in other reports. Wang (2011a) found that the maximum soil temperatures in the soil surface layer were $4^{\circ} \mathrm{C}$ to $6^{\circ} \mathrm{C}$ lower in straw mulched plots than in non-mulched plots. Kar (2003) showed that the soil temperature was $3^{\circ} \mathrm{C}$ to $4^{\circ} \mathrm{C}$ less in rice straw-mulched plots than in nonmulched plots. Samad (2014) confirmed that Arachis pintoi and rice straw mulch effectively decreased soil temperatures. Plastic mulch produces a greater temperature effect than rice straw mulch, because plastic mulch has no pores for water movement and the black-coloured plastic absorbs more light from the sun (Samad, 2014). In our research, the tuber yield in rice straw mulch was $9.4 \%$ and $8.0 \%$ greater than that of bare soil in 2013 to 2014 and 2014 to 2015, respectively (Table 6). Higher yields were observed in other reports (Kar and Kumar, 2007; Samad et al., 2014), which might be due to the conservation of soil moisture and favourable soil temperatures.

In both natural and agricultural ecosystems, soil microorganisms play key roles in the recycling of elements, and they are essential for biological processes. Because microorganisms respond to stressful conditions, soil microorganism counts and activity level assessments are useful for estimating the soil's fertility. Here, the total amount of bacteria increased, while the fungi and actinomycetes decreased after harvesting compared with before sowing (Table 8). In addition, there was no consistence trend in the microorganismal changes, except the significant decline in total fungal counts under 
the white plastic mulch (Table 8). On the contrary, ordinary plastic mulch increased yields led to no significant decreases in the total microbial diversity compared with nonmulched soil (Kapanen et al., 2008; Liu et al., 2012; Chen et al., 2014). However, Continuous plastic-film mulching sowed increasing in microbial activity (Wang et al., 2017). Additional, plastic mulch in asparagus crops induce changes on the incidence and distribution of the mycotoxin deoxynivalenol in soil, and also on the mycobiome abundance and diversity, with a positive selection of Fusarium species at the root zone (Muñoz et al., 2015). However, mulching changed other soil fertility associated properties. The content of available nitrogen was significantly increased by rice straw mulch in both growing seasons, and no tillage was beneficial to releasing straw nitrogen. The contents of available phosphorus and potassium significantly increased under mulching compared with non-mulching in the 2013 to 2014 growing season, while in the 2014 to 2015 growing season, the contents of the available phosphorus and potassium decreased significantly under rice straw and white plastic mulch, respectively (Table 7). The two year experimental period was too short to determine any wellregulated changes. To understand the environmental and agronomic effects of mulching, comparative and long-term agronomic assessments need to be conducted (Steinmetz et al., 2016).

\section{Conclusion}

In our study, black plastic mulch increased the soil temperature and was more suitable for potato emergence and tuber bulk in winter potato production in South China. Furthermore, the emergence rate, and above- and under-ground biomass, also increased. Finally, potato yields were significantly increased. Therefore, mulching with black plastic film is an effective farming practice for winter potato production in the Typical Pearl River Delta Plain of south China, or other typical sub-tropical monsoon regions with similar climate.

Acknowledgements. We thank Dr. Jing Lü for comments and revisions on an earlier version of the manuscript. The experiments comply with the current laws of the China. This study was funded by the Science and Technology Planning Project of Guangdong Province (2017B020203002 , 2016A020207002, 2017A020208021); the Technology Research and Development Subsidies Project of Department of Finance of Guangdong Province (639) to YueCaiGong in 2015; and the Scientific Research Special Fund of Public Welfare Industry (Agriculture) (201503123-03), the Develop Grain Production Project of Guangdong Province (27) to YueNongJi in 2017.

\section{REFERENCES}

[1] Anikwe, M. A. N., Mbah, C. N., Ezeaku, P. I., Onyia, V. N. (2007): Tillage and plastic mulch effects on soil properties and growth and yield of cocoyam (Colocasia esculenta) on an ultisol in southeastern Nigeria. - Soil \& Tillage Research 93: 264-272.

[2] Baghour, M., Moreno, D. A., Hernández, J., Castilla, N., Romero, L. (2002): Influence of root temperature on uptake and accumulation of $\mathrm{Ni}$ and $\mathrm{Co}$ in potato. - Journal of Plant Physiology 159: 1113-1122.

[3] Chen, Y., Wen, X., Sun, Y., Zhang, J., Wu, W., Liao, Y. (2014): Mulching practices altered soil bacterial community structure and improved orchard productivity and apple quality after five growing seasons. - Scientia Horticulturae 172: 248-257. 
[4] Delden, A. V., Pecio, A., Haverkort, A. J. (2000): Temperature response of early foliar expansion of potato and wheat. - Annals of Botany-London 86: 355-369.

[5] Díaz, J. C. (2002): Colored plastic film mulches affect tomato growth and yield via changes in root-zone temperature. - Journal of the American Society for Horticultural Science 127: 127-135.

[6] Díaz-Pérez, J. C. (2009): Root zone temperature, plant growth and yield of broccoli [Brassica oleracea (Plenck) var. italica] as affected by plastic film mulches. - Scientia Horticulturae 123: 156-163.

[7] Díaz-Pérez, J. C., Phatak, S. C., Giddings, D., Bertrand, D., Mills, H. A. (2005): Root zone temperature, plant growth, and fruit yield of tomatillo as affected by plastic film mulch. - Hortscience 40: 1312-1319.

[8] Du, S., Gao, X. Z., Li, H. F., Lu, R. H., Jiang, Q. Q. (2004): Determination of exchangeable potassium and no-exchangeable potassium content in soil. - NY/T8892004:1-3.

[9] Duan, X. Y., Yang, R. R., Lv, Y. H., Zhang, X. F., Xie, H., Liu, X. L., Zhao, L. (2007): Determination of soil available nitrogen. - DB13/T 843-2007:1-3.

[10] Dvořák, P., Tomášek, J., Kuchtová, P., Hamouz, K., Hajšlová, J., Schulzová, V. (2012): Effect of mulching materials on potato production in different soil-climatic conditions. Romanian Agricultural Research 29: 201-209.

[11] Ghosh, P. K., Dayal, D., Bandyopadhyay, K. K., Mohanty, M. (2006): Evaluation of straw and polythene mulch for enhancing productivity of irrigated summer groundnut. - Field Crops Research 99: 76-86.

[12] Hay, R. K. M., Allen, E. J. (1978): Tuber initiation and bulking in the potato under tropical conditions: the importance of soil and air temperature. - Tropical Agriculture, Trinidad 55: 289-296.

[13] Hou, X. Y., Wang, F. X., Han, J. J., Kang, S. Z., Feng, S. Y. (2010): Duration of plastic mulch for potato growth under drip irrigation in an arid region of Northwest China. Agricultural and Forest Meteorology 150: 115-121.

[14] Ibarra-Jiménez, L., Lira-Saldivar, R. H., Valdez-Aguilar, L. A., Río, J. L. D. (2011): Colored plastic mulches affect soil temperature and tuber production of potato. - Acta Agriculturae Scandinavica Section B-Soil and Plant Science 61: 365-371.

[15] Jiao, R. Z., Dong, Y. H., Sun, Q. W. (2015): Phosphorus determination methods of restsoils. - LY/T 1232-2015:6-12.

[16] Johnie, R. S., Josiah, W. W. (1998): Modifying heat unit accumulation with contrasting colors of polyethylene mulch. - Hortscience A Publication of the American Society for Horticultural Science 33: 210-214.

[17] Kapanen, A., Schettini, E., Vox, G., Itävaara, M. (2008): Performance and environmental impact of biodegradable films in agriculture: A field study on protected cultivation. Journal of Polymers and the Environment 16: 109-122.

[18] Kar, G. (2003): Tuber yield of potato as influenced by planting dates and mulches. Journal of Agrometeorology 5: 60-67.

[19] Kar, G., Kumar, A. (2007): Effects of irrigation and straw mulch on water use and tuber yield of potato in eastern India. - Agricultural Water Management 94: 109-116.

[20] Li, F. M., Guo, A. H., Hong, W. (1999): Effects of clear plastic film mulch on yield of spring wheat. - Field Crops Research 63: 79-86.

[21] Li, F. M., Wang, J., Xu, J. Z., Xu, H. L. (2004): Productivity and soil response to plastic film mulching durations for spring wheat on entisols in the semiarid Loess Plateau of China. - Soil \& Tillage Research 78: 9-20.

[22] Liu, C. A., Jin, S. L., Zhou, L. M., Jia, Y., Li, F. M., Xiong, Y. C., Li, X. G. (2009): Effects of plastic film mulch and tillage on maize productivity and soil parameters. - European Journal of Agronomy 31: 241-249. 
[23] Liu, Y., Lin, M., He, X., Gang, C., Ma, X., An, L., Feng, H. (2012): Rapid change of AM fungal community in a rain-fed wheat field with short-term plastic film mulching practice. - Mycorrhiza 22: 31-39.

[24] Liu, Y., Yang, H. S., Li, Y. F., Yan, H. J., Li, J. S. (2017): Modeling effects of plastic film mulching on irrigated maize yield and water use efficiency in sub-humid Northeast China. - International Journal of Agricultural \& Biological Engineering 10(5): 69-84.

[25] Mahmood, M. M., Farooq, K., Hussain, A., Sher, R. (2002): Effect of mulching on growth and yield of potato crop. - Asian Journal of Plant Sciences 1:132-133.

[26] Martin, J. P. (1950): Use of acid, rose bengal and streptomycin in the plate method for estimating soil fungi. - Soil Science 69: 215-232.

[27] Muñoz, K., Schmidt-Heydt, M., Stoll, D., Diehl, D., Ziegler, J., Geisen, R., Schaumann, G. E. (2015): Effect of plastic mulching on mycotoxin occurrence and mycobiome abundance in soil samples from asparagus crops. - Mycotoxin Research 31: 191-201.

[28] Pat, B., Brenda, F. (2002): Response of plasticultured bell pepper to staking, irrigation frequency, and fertigated nitrogen rate. - Horticultural Science 37: 95-100.

[29] Ramakrishna, A., Tam, H. M., Wani, S. P., Long, T. D. (2006): Effect of mulch on soil temperature, moisture, weed infestation and yield of groundnut in northern Vietnam. Field Crops Research 95: 115-125.

[30] Romic, D., Romic, M., Borosic, J., Poljak, M. (2003): Mulching decreases nitrate leaching in bell pepper (Capsicum annuиm L.) cultivation. - Agricultural Water Management 60: 87-97.

[31] Ruízmachuca, L. M., Ibarrajiménez, L., Valdezaguilar, L. A., Robledotorres, V., Benavidesmendoza, A., Fuente, C. D. L. (2014): Cultivation of potato - use of plastic mulch and row covers on soil temperature, growth, nutrient status, and yield. - Acta Agriculturae Scandinavica Section B-Soil and Plant Science 65: 30-35.

[32] Samad, S., Mustafa, M., Baharuddin, Rampisela, D. A. (2014): The effect of mulch and fertilizer on soil temprature of a potato growth. - International Journal of Agriculture Systems 1: 91-102.

[33] Steinmetz, Z., Wollmann, C., Schaefer, M., Buchmann, C., David, J., Tröger, J., Muñoz, K., Frör, O., Schaumann, G. E. (2016): Plastic mulching in agriculture. Trading short-term agronomic benefits for long-term soil degradation? - Science of the Total Environment 550: 690-705.

[34] Triki, M. A., Priou, S., Mahjoub, M. E. (2001): Effects of soil solarization on soil-borne populations of Pythium aphanidermatum and Fusarium solani and on the potato crop in Tunisia. - Potato Research 44: 271-279.

[35] Vos, J. G. M., Uhan, T. S., Sutarya, R. (1995): Integrated crop management of hot pepper (Capsicum spp.) under tropical lowland conditions: Effects of rice straw and plastic mulches on crop health. - Crop Protection 14: 445-452.

[36] Wang, F. X., Feng, S. Y., Hou, X. Y., Kang, S. Z., Han, J. J. (2009): Potato growth with and without plastic mulch in two typical regions of Northern China. - Field Crops Research 110: 123-129.

[37] Wang, F. X., Wu, X. X., Shock, C. C., Chu, L. Y., Gu, X. X., Xue, X. (2011a): Effects of drip irrigation regimes on potato tuber yield and quality under plastic mulch in arid Northwestern China. - Fuel \& Energy Abstracts 122: 78-84.

[38] Wang, F. X., Xiu, X. W., Clinton, C. S., Chu, L. Y., Gu, X. X., Xue, X. (2011b): Effects of drip irrigation regimes on potato tuber yield and quality under plastic mulch in arid Northwestern China. - Field Crops Research 122: 78-84.

[39] Wang, L., Li, X. G., Lv, J., Fu, T. T., Ma, Q. J., Song, W. Y., Wang, Y. P., Li, F. M. (2017): Continuous plastic-film mulching increases soil aggregation but decreases soil $\mathrm{pH}$ in semiarid areas of China. - Soil \& Tillage Research 167:46-53.

[40] Wang, X. L., Li, F. M., Jia, Y., Shi, W. Q. (2005): Increasing potato yields with additional water and increased soil temperature. - Agricultural Water Management 78: 181-194. 
[41] Wolf, S., Marani, A., Rudich, J. (1990): Effects of temperature and photoperiod on assimilate partitioning in potato plants. - Annals of Botany-London 66: 513-520.

[42] Wollum, A. G. (1982): Cultural Methods for Soil Microorganisms. - In: Page, A. L., Miller, R. H., Keeney, D. R. (eds.) Methods of Soil Analysis. Part 2. Chemical and Microbiological Properties. American Society of Agronomy, Madison, WI.

[43] Zhang, F., Zhang, W., Qi, J., Li, F. M. (2017b): A regional evaluation of plastic film mulching for improving crop yields on the loess plateau of china. - Agricultural \& Forest Meteorology 248: 458-468.

[44] Zhang, Y. L., Wang, F. X., Shock, C. C., Yang, K. J., Kang, S. Z., Qin, J. T., Li, S. E. (2017a): Influence of different plastic film mulches and wetted soil percentages on potato grown under drip irrigation. - Agricultural Water Management 180:160-171.

[45] Zhao, H., Xiong, Y. C., Li, F. M., Wang, R. Y., Qiang, S. C., Yao, T. F., Mo, F. (2012): Plastic film mulch for half growing-season maximized WUE and yield of potato via moisture-temperature improvement in a semi-arid agroecosystem. - Agricultural Water Management 104: 68-78.

[46] Zhao, H., Wang, R. Y., Ma, B. L., Xiong, Y. C., Qiang, S. C., Wang, C. L., Liu, C. A., Li, F. M. (2014): Ridge-furrow with full plastic film mulching improves water use efficiency and tuber yields of potato in a semiarid rainfed ecosystem. - Field Crops Research 161: 137-148.

[47] Zhou, L. M., Jin, S. L., Liu, C. A., Xiong, Y. C., Si, J. T., Li, X. G., Gan, Y. T., Li, F. M. (2012): Ridge-furrow and plastic-mulching tillage enhances maize-soil interactions: Opportunities and challenges in a semiarid agroecosystem. - Field Crops Research 126: 181-188. 